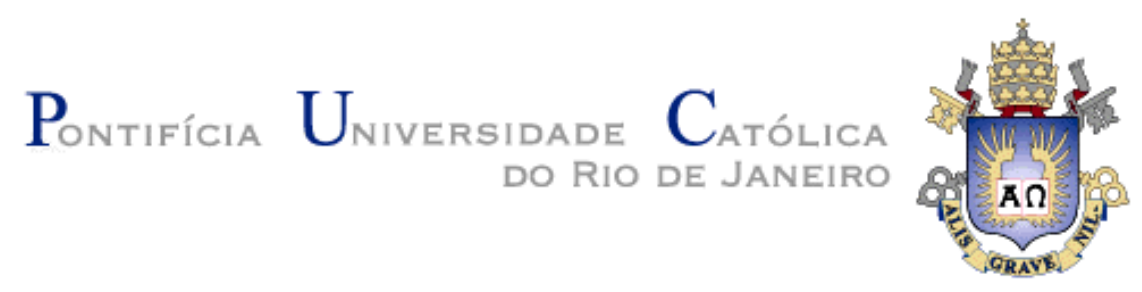

Everton Tavares Guimarães

\title{
A Blueprint-Based Approach for Prioritizing and Ranking Critical Code Anomalies
}

Thesis presented to the Programa de PósGraduação em Informática of the Departamento de Informática, PUC-Rio as partial fulfillment of the requirements for the degree of Doutor em Informática

Advisor: Prof. Alessandro Fabricio Garcia 


\title{
Pontifícia Universidade Católica $_{\text {a }}$

\section{Everton Tavares Guimarães}

\section{A Blueprint-Based Approach for Prioritizing and Ranking Critical Code Anomalies}

\begin{abstract}
Thesis presented to the Programa de PósGraduação em Informática, of the Departamento de Informática do Centro Técnico Científico da PUC-Rio, as partial fulfillment of the requirements for the degree of Doutor.
\end{abstract}

\author{
Prof. Alessandro Fabricio Garcia \\ Advisor \\ Departamento de Informática - PUC-Rio \\ Prof. Julio Cesar Sampaio do Prado Leite \\ Departamento de Informática - PUC-Rio \\ Prof. Alberto Raposo Tavares \\ Departamento de Informática - PUC-Rio \\ Prof. Thais Vasconcelos Batista \\ UFRN \\ Prof. Eduardo Magno Lages Figueiredo \\ UFMG \\ Prof. José Eugenio Leal
} Coordinator of the Centro Técnico Científico da PUC-Rio Rio de Janeiro, September 12th, 2014 
All rights reserved.

\section{Everton Tavares Guimarães}

He completed his undergraduate studies in the Federal Institute of Science, Education and Technology of Rio Grande do Norte in 2009. He received his Master degree in Computer Science from the Federal University of Rio Grande do Norte (UFRN) in 2010. His research topics include software evolution, software product lines, software modularity, software metrics, aspect-oriented software development, model-driven development, code anomalies and empirical studies.

Bibliographic data

Guimarães, Everton Tavares
A Blueprint-Based Approach for Prioritizing and Ranking
Critical Code Anomaliess / Everton Tavares Guimarães; advisor:
Alessandro Fabrício Garcia - 2014 .
142 f. : il. ; $30 \mathrm{~cm}$
Tese (Doutorado em Informática)-Pontifícia Universidade
Católica do Rio de Janeiro, Rio de Janeiro, 2014.
Inclui referências bibliografias
1. Informática - Teses. 2. Anomalias de Código. 3. Projeto
Arquitetural. 4. Blueprints. 5. Métricas de Software. 5. Estudos
Empíricos. 5. Heurísticas Sensíveis a Arquitetura. I. Garcia,
Alessandro Fabricio. II. Pontifícia Universidade Católica do Rio de
Janeiro. Departamento de Matemática. IV. Título.

CDD: 004 
To all my friends, family and fiancée.

To all dear colleagues at the OPUS Research Group. To my advisor, who guided me through this uneasy research for the last four years. Thank you for your patience, kindness and wisdom. 


\section{Acknowledgments}

First of all, I would like to thank God for all the blessings in my life and for giving me strength and persistence to overcome all the challenges and barriers I have found in the last four years.

I would like to express my sincere gratitude to Prof. Alessandro Garcia, who agreed to be my supervisor and helped me in preparing this thesis despite his busy schedule. Thank you for your availability, patience, and for all the knowledge and experience you have shared with me during this journey. His professionalism, dedication and energy for work are exemplary. Above all, thanks for the friendly relationship built over these four years.

I would like to thank my parents, Alvaro and Marilsa, for all the love and support. They have not supported me in this journey, but also for all the many other challenges in my life. They have been especially important and played a critical role in the completion of this thesis. I have no words to describe how blessed I am to be your son.

I would like to express my gratitude to my fiancée Annanda for being by my side either in the good or bad moments. Her dedication, discipline and patience are inspiring. Your love, affection and understanding were the driving force to keep me I reached this goal (specially during the last year).

Thanks to all my friends at PUC-Rio, and many other friends I have met in Rio. I would like to thank for your friendship. It is great pleasure for me to be in your presence and enjoy. Meet them in his spare time are always a boost to continue working. I wish I could name all my friends and loved ones who have been there for me during this journey graduate school, but there are simply too many to list. However, I would like to thank Michele and José for all the support, friendship, and advices. Thanks for and for being my friends unconditionally. 
I would like to thank all friends of courses taken in the master for the fellowship, encouragement in difficult times and relaxed moments. Without your company, my journey would have been much more difficult.

I would like to thank all the friends and colleagues of LES and the members of the OPUS research group. Your comments and discussions are always enriching. In particular, thanks to Soeli, Francisco, Bruno, Eiji, and Isela who has also participated with me in many research projects, and therefore, have more closely contributed to my doctoral research.

I would like to thank all the teachers of the Department of Informatics, PUC-Rio for the contribution in my education. I also thank all the staff of the department for their services. 


\section{Abstract}

Guimarães, Everton Tavares; Garcia, Alessandro Fabricio, Alessandro Fabrício (Advisor). A Blueprint-Based Approach for Prioritizing and Ranking Critical Code Anomalies, 2014. 142p. DSc Thesis Departamento de Informática, Pontifícia Universidade Católica do Rio de Janeiro.

Software systems are often evolving due to many changing requirements. As the software evolves, it grows in size and complexity, and consequently, its architecture design tends to degrade. Architecture degradation symptoms are often a direct consequence of the progressive insertion of code anomalies in the software implementation. A code anomaly is a recurring implementation structure that possibly indicates deeper architectural design problems. Code anomaly is considered critical when it is related with a structural problem in the software architecture. Its criticality stems from its negative influence on a wide range of non-functional requirements. For instance, the presence of critical code anomalies hinders software maintainability, i.e. these critical anomalies require wide refactoring in order to remove an architectural problem. Symptoms of architecture degradation have often to be observed in the source code due to the lack of an explicit, formal representation of the software architecture in a project. Many approaches are proposed for detecting code anomalies in software systems, but none of them efficiently support the prioritization and ranking of critical code anomalies according to their architecture impact. Our work investigates how the prioritization and ranking of such critical code anomalies could be improved by using blueprints. Architecture blueprints are usually provided by software architects since the early stages of the system development. Blueprints are informal design models usually defined to capture and communicate key architectural design decisions. Even though blueprints are often incomplete and inconsistent with respect to the underlying implementation, we aim to study if their use can contribute to improve the processes of prioritizing and ranking critical code anomalies. Aiming to address these research goals, a set of empirical studies has been performed. We also proposed and evaluated a set of 
heuristics to support developers when prioritizing and ranking code anomalies in 3 software systems. The results showed an average accuracy higher than $60 \%$ when prioritizing and ranking code anomalies associated with architectural problems in these systems.

\section{Keywords}

Code Anomalies; Architecture Design; Blueprints; Software Metrics; Empirical Studies; Architecture Sensitive Heuristics; 


\section{Resumo}

Guimarães, Everton Tavares; Garcia, Alessandro Fabricio. Uma Abordagem Baseada em Blueprints para Priorização e Classificação de Anomalias de Código Críticas. Rio de Janeiro, 2014. 142p. Tese de Doutorado - Departamento de Informática, Pontifícia Universidade Católica do Rio de Janeiro.

Sistemas de software estão evoluindo frequentemente devido a diversas requisições de mudanças. A medida que o software evolui, seu tamanho e complexidade aumentam, e consequentemente, sua arquitetura tende a se degradar. Sintomas de degradação arquitetural são por muitas vezes uma consequência direta da inserção progressiva de anomalias de código. Uma anomalia de código é uma estrutura da implementação recorrente que possivelmente indica problemas mais severos no projeto arquitetural. Anomalia de código é considerada crítica quando ela está relacionada problemas estruturais na arquitetura do software. Sua criticidade origina-se da sua influência negativa em uma ampla gama de requisitos não-funcionais. Por exemplo, a presença e anomalias e código críticas dificulta a manutenibilidade e software., ex. uma grande refatoração pode ser necessária para remover um problema arquitetural. Diversas abordagens tem sido propostas para a detecção de anomalias em sistemas de software, mas nenhuma delas suporta eficientemente a priorização e classificação de anomalias de código críticas de acordo com seu impacto na arquitetura. $\mathrm{O}$ presente trabalho investiga como a priorização e classificação dessas anomalias críticas de código pode se melhorado com o uso de blueprints arquiteturais. Blueprints arquiteturais são providos pelo arquiteto de software desde estágios iniciais de desenvolvimento do sistema. Blueprints são modelos de projeto informais normalmente definidos para capturar e comunicar as principais decisões de projeto arquitetural. Embora blueprints normalmente sejam incompletos e inconsistentes com respeito a implementação do sistema, eles podem contribuir para o processo de priorização e classificação de anomalias de código críticas. Com o intuito de alcançar nossos objetivos de pesquisa, um conjunto de estudos empíricos foram realizados. O trabalho também propõe e avalia um conjunto de heurísticas para auxiliar 
desenvolvedores na priorização e classificação de anomalias de código em 3 sistemas de software. Os resultados mostraram uma acurácia média de mais de $60 \%$ na priorização e classificação de anomalias de código associadas com problemas arquiteturais nesses sistemas.

\section{Palavras-Chave}

Anomalias de Código; Projeto Arquitetural; Blueprints; Métricas;

Estudos Empíricos; Heurísticas Sensíveis a Arquitetura; 


\section{Table of Contents}

1 Introduction 16

$\begin{array}{ll}\text { 1.1. Motivation } & 17\end{array}$

1.2. Problem Statement 21

1.3. Limitations of Related Work 23

1.4. Proposed Solution $\quad 24$

1.5. Research Questions 28

1.6. Outline of the Thesis Structure 30

2 Background and Related Work 33

2.1. Basic Terminology 34

2.1.1. Software Architecture 34

2.1.2. Architecture Degradation Symptoms 35

2.2. Code Anomalies as Architecture Degradation Symptoms 38

2.2.1. Refactoring Process and Removal of Code Anomalies 39

2.2.2. Co-occurrence of Critical Code Anomalies 40

2.2.3. Classifying Occurrences of Code Anomalies 42

2.3. Tool Support for Code Anomaly Detection 43

2.3.1. Prioritization and Ranking of Code Anomalies 44

2.4. Prioritization of Code Anomalies Supported by Blueprints 46

2.4.1. Level of Abstraction 48

2.4.2. Completeness 49

2.4.3. Inconsistencies $\quad 50$

2.4.4. Mapping Architecture Blueprints to Source Code 51

2.5. Summary 53

3 On the Relation of Blueprints and Code Anomalies: A Study of Evolving Software Systems

3.1. Aspect-Oriented Software Development 56

3.2. Aspect-Oriented Modeling 59

$\begin{array}{ll}\text { 3.3. Study Settings } & 61\end{array}$

3.3.1. Target Systems $\quad 62$ 
3.3.2. Quantifying Modularity Properties and Inconsistencies 63

3.3.3. Study Phases and Assessment Procedures 64

3.4. Hypotheses Testing and Initial Research Findings 66

3.5. Code Anomalies and Inconsistencies in the Descriptive Architecture 68

$\begin{array}{ll}\text { 3.6. Summary } & 73\end{array}$

4 Prioritizing and Ranking Code Anomalies with Blueprints 75

4.1. Code Anomalies Studied 76

$\begin{array}{ll}\text { 4.2. Experimental Evaluation } & 77\end{array}$

$\begin{array}{ll}\text { 4.2.1. Experimental Steps } & 79\end{array}$

4.2.2. Ground Truth of Code Anomalies 81

4.3. Hypotheses Testing and Data Analysis $\quad 81$

4.3.1. Impact of Architecture Blueprints On Precision and Recall 83

4.3.2. Analyzing the Time Spent on the Prioritization Process 84

4.4. Further Discussions $\quad 85$

4.4.1. Usefulness of Architecture Blueprints 86

4.4.2. Participants' Technical Knowledge 87

4.4.3. Mapping Architecture Blueprints to Source-Code 88

4.4.4. Critical Code Anomalies and False Positives 89

4.4.5. Architecture Blueprints and False Negatives 92

4.5. Summary 93

5 Architecture Sensitive Heuristics for Prioritizing and Ranking Critical Code $\begin{array}{ll}\text { Anomalies } & 96\end{array}$

5.1. Criteria Selection and Relation to Architectural Problems 98

5.2. Study Settings 99

5.3. Heuristics for Prioritizing and Ranking Critical Code Anomalies 102

5.3.1. Inter-Component Heuristics 102

5.3.1.1. Heuristic Based External Attractor Component 103

5.3.1.2. Heuristic Based on External Addictor Component 105

5.3.2. Concern-Based Heuristics 106

$\begin{array}{ll}\text { 5.3.2.1. Heuristic for Concern Overload } & 107\end{array}$

$\begin{array}{ll}\text { 5.3.2.2. Heuristic for Misplaced Concern } & 109\end{array}$

5.4. Research Findings on Prioritizing and Ranking Critical Code Anomalies 110

5.4.1. Procedures for Data Collection and Evaluation Method 110 
$\begin{array}{ll}\text { 5.4.3. Inter-Component Heuristics } & 114\end{array}$

$\begin{array}{ll}\text { 5.4.4. Concern-Based Heuristics } & 116\end{array}$

5.4.5. Accuracy of the Architecture Sensitive Heuristics 119

$\begin{array}{ll}\text { 5.5. Discussions } & 120\end{array}$

$\begin{array}{ll}\text { 5.5.1. Identifying False Positives and False Negatives. } & 121\end{array}$

5.5.2. Comparing Ranking Provided by Different Heuristics 122

$\begin{array}{ll}\text { 5.6. Summary } & 124\end{array}$

$\begin{array}{lr}6 \text { Final Remarks } & 127\end{array}$

$\begin{array}{ll}\text { 6.1. General Threats to Validity } & 127\end{array}$

$\begin{array}{lr}\text { 6.2. Revisiting the Thesis Contributions } & 128\end{array}$

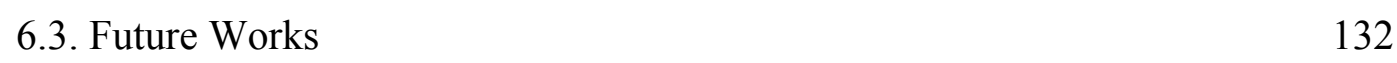

$\begin{array}{ll}\text { References } & 135\end{array}$ 


\section{List of Figures}

Figure 1 - Code Fragments with Non-Critical and Critical Code Anomalies..............19

Figure 2 - Architecture Blueprint of Mobile Media SPL.............................................48

Figure 3 - Mapping Component to Source-Code........................................................52

Figure 4 - AOM notation for architecture blueprints ...............................................59

Figure 5 - Information Suggested by Participants..................................................59

Figure 6 - Scenario for External Attractor Component............................................. 104

Figure 7 - Scenario for External Addictor Component ............................................ 106

Figure 8 - Scenario for Misplaced Concern ........................................................... 108 


\section{List of Tables}

Table 1 - Architectural problems considered in this work ...........................................36

Table 2 - Correlation between Inconsistencies and AO Modularity Properties ..........67

Table 3 - Anomalies in AO Taget Application .......................................................... 71

Table 4 - Code Anomalies in Health Watcher and Mobile Media...............................71

Table 5 - Correlation between Code Anomalies and Inconsistencies ..........................72

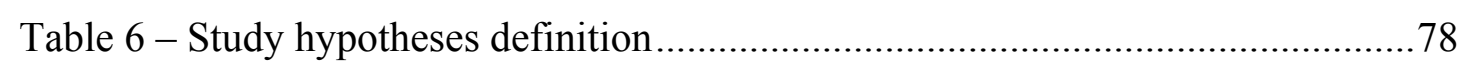

Table 7 - Code anomalies reference list for Mobile Media.........................................81

Table 8 - Definition of Precision and Recall ............................................................82

Table 9 - Descriptive statistic for Precision and Recall ...........................................83

Table 10 - Descriptive statistic for Time Spent on the prioritization process ..............85

Table 11 - Analyzing consistency and Completeness of architecture blueprint..........89

Table 12 - Characteristics of False Positives ............................................................ 91

Table 13 - Software Metrics and False Positives......................................................99

Table 14 - False Negatives by Participants' Group ....................................................93

Table 15 - Study Definition using GQM format.................................................... 101

Table 16 - Study Hypothesis for Evaluating the Heuristics...................................... 101

Table 17 - Additional Architecture Sensitive Metrics .............................................. 112

Table 18 - Characteristics of Target Applications .................................................... 113

Table 19 - Results for Inter-Component Heuristics ................................................115

Table 21 - Architectural Concerns for Health Watcher and Mobile Media...............119

Table 21 - Results for Concern Based Heuristics ...................................................119

Table 22 - False positives and negatives achieved by the prioritization heuristics ...121

Table 23 - Relevance based on the system history evolution .................................. 123 